\title{
Series
}

\section{地すべりキーワード101(ワン・オー・ワン) -30-}

\section{第四紀火山と地すべり}

\section{Landslides on Quaternary Volcanoes}

小松原 琢 Taku KOMATSUBARA／産業技術総合研究所 Geological Survey of Japan, AIST

\section{1.はじめに}

火山地帯に地すべりが多いことは，古くから知られて いる事実です。その原因として，以前は温泉（熱水）変 質作用のような火山岩の変質・風化作用が強調されてお り (たとえば小出 $\left.(1955)^{1)}\right)$, 火山特有の地形や地質構 造と地すべりの関連が明らかにされたのは比較的最近の ことです。

ここでは，第四紀火山の地形・地質学的な特徴を概観 し，地すべりの素因についてまとめてみます。

\section{2. 第四紀火山の地形・地質}

第四紀火山は，火山の原型を保っていることが多く， 標高は山頂近くの噴出源（火口）が最も高く，裾野に向 かって徐々に低くなる地形をもつものが大半を占めてい ます。そして，多くの場合，火山の地質は，地形とほほ 平行に比較的硬く透水性の高い溶岩と, 固結度が低いテ フラ（火山灰・軽石・灭山礫など火山から噴出・降下 した物質及び火砕流堆積物を含む火山砕居物を総称した もの。固結したものは凝灰岩）が積み重なった構造をな しています（図－1）。

このような地形と地質構造のため，カルデラ壁を例外 として，火山体全体が硬軟互層，かつ透水層と難透水層 の互層からなる流れ盤斜面となっている例が多く見られ

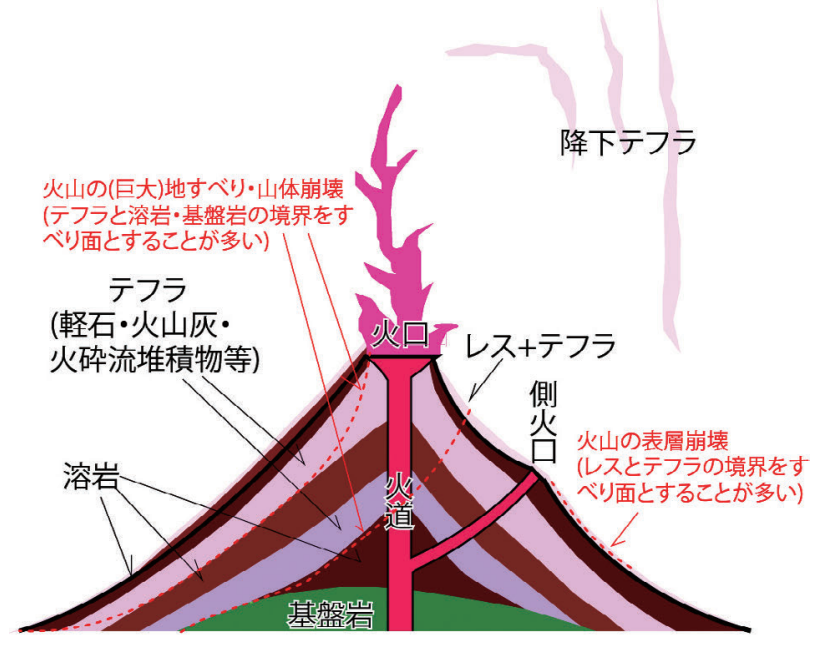

図－1 火山体の摸式断面（構造的な変形を大きく受けてい ない第四紀火山の火山体)
ます。火山体を構成する岩石の中では比較的硬いとされ る溶岩もガスを含んだ状態で地表ないし水底を流れて堆 積した地層であるため，元来気孔や割れ目が多く，引張 強度は決して強くありません。いわば山全体が脆く，崩 れやすい地質でできていると言っても過言ではありませ ん。このことは火山（特に第四紀火山）で巨大な地す心゙ りが生じやすい根本的な要因と言えます。

\section{3. 熱水（温泉）変質作用と火山}

火山は熱の給源であるマグマだまりを地下に伴ってお り，そこから水蒸気や硫化水素，二酸化炭素などさまざ まな成分を持つ液体と気体が放出されます。それらは火 山体とその周辺の岩石中の割れ目を伝って地表に噴出し ます。熱水 (温泉) 変質とは, この過程で火山体周辺の 地層が変質し，特有の粘土鉱物が生じる作用です。岩石 が熱水 (温泉) 変質を受けると, モンモリロナイトやイ ライトに代表される水を含みやすく膨潤性に富む粘土鉱 物が形成されます。このため，熱水で変質した地層は， 水を含むことによってより一層すべりやすくなり, すべ り面へと発達することも少なくありません。とりわけ火 山体に広く分布するテフラは，熱水変質を被ってモンモ リロナイトに変質しやすく，かつテフラは一般に層状に 連続して分布するため, 変質したテフラは大規模な地す べりのすべり面になりやすいといえます。

\section{4. 第四紀火山で生じた地すべりの例}

以上のような地形・地質的な素因が重なり合って，第 四紀火山体では，巨大な地すべりを生じることがありま す。また，富士山のような非常に若い火山を除けば，一 般に地すべり地形は火山体の至る所に認められます。

歴史時代にも様々な現象を誘因として第四紀火山で地 すべりや崩壊が発生しています。そのいくつかを紹介し ましょう。

\section{1 大蔦（立山）崩れ}

大氙崩れは，北アルプス北部・立山連峰の南西に位置 する長径約 $7.5 \mathrm{~km}$, 短径約 $3 \mathrm{~km}$ の「侵食カルデラ」と 呼ばれる凹地（図－2）の西半分で生じた地すべりです。 この地すべりは1858年の安政飛越地震（マグニチュー ド7.1）を誘因として，立山の南にそびえていた大氙山・ 


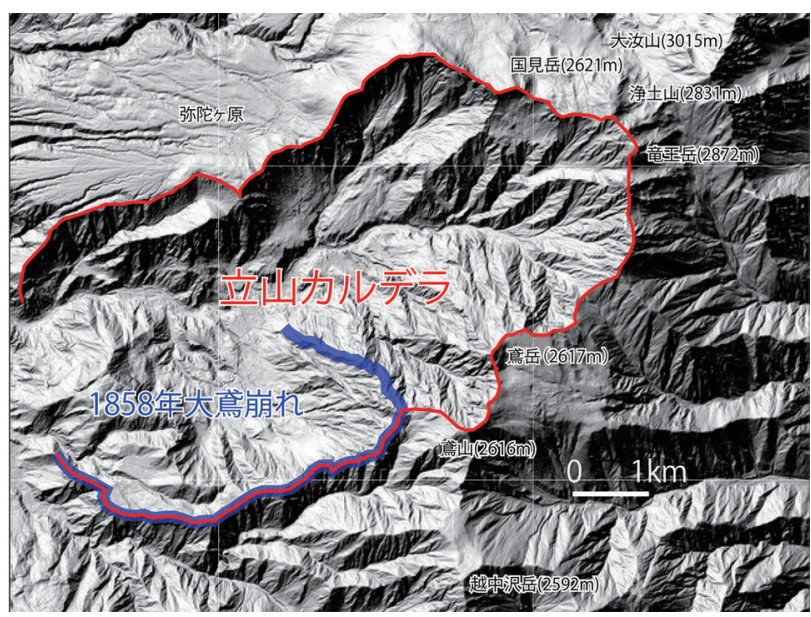

図一2 大蔦崩れと立山カルデラ（地理院地図に加筆）。 大蔦崩れの範囲は野崎・菊川 $(2012)^{2)}$ による

小武山が崩落したもので，その移動土砂量約 2 億 $\mathrm{m}^{3}$ （藤 井ほか, 2011) 3，日本の歴史時代における単一の地す べりとしては次に述べる磐梯山の山体崩壊に次ぐ規模で す。この地震地すべりは，常願寺川をせき止めて天然ダ ムを形成しました。天然ダムは，地震の14日後および59 日後の 2 度にわたって決壊し, 常願寺川下流の広い範囲 に土石流と洪水流を引き起こしました。大式崩れは山の 中に膨大な不安定土砂を残しているため, 発生後150年 以上を経た今も国の直轄事業として砂防工事が続けられ ています。

\section{2 磐梯山の水蒸気爆発に伴う山体崩壊}

福島県の磐梯山 $(1882 \mathrm{~m})$ は，秀麗な地形 (写真 -1 ) で知られる火山ですが，現在の地形は1888年の噴火（水 蒸気爆発）とそれに伴う山体崩壊によって形づくられま した。

この噴火は火山噴出物の量は少なく, 火山噴火として は決して規模の大きなものではありませんが，水蒸気爆 発に伴って火山体北部の約 10 億 $\mathrm{m}^{3}\left(=1 \mathrm{~km}^{3}\right)$ が一挙に 崩れ落ちて，山麓を流れる長瀬川をせき止めました。通 称「爆裂火口」と呼ばれる，岩肌が露出した馬蹄形の崖 （写真－1）は，実は火口ではなく山体崩壊時に山が滑 り落ちた崩壊壁です (井口, 1988) ${ }^{4)}$ 。

\section{3 御岳 (伝上) 崩れ}

御岳崩れは, 1984年の長野県西部地震（マグニチュー

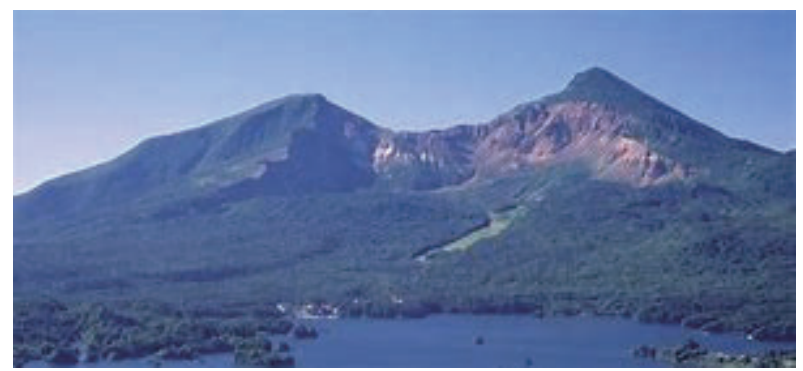

写真一 1 北面から見た磐梯山

（磐梯山噴火記念館ホームページょり）

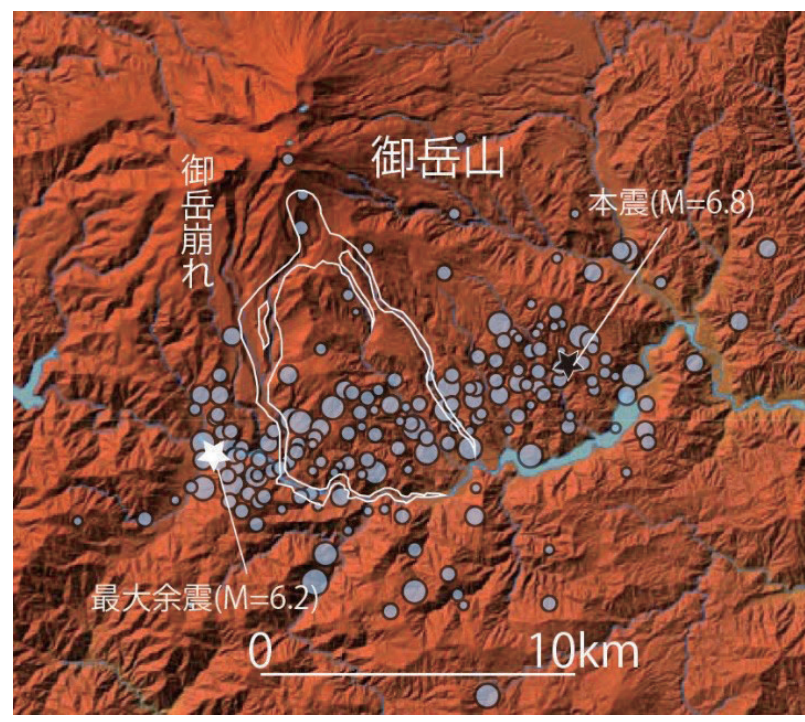

図－3＼cjkstart御岳崩れと長野県西部地震の本震・余震分布

ド6.8）に伴って御岳山南斜面に位置する尾根状斜面が 崩れ落ちたものです (図 -3$)$ 。

この地震地すべりにより, $3400 \mathrm{~m}^{3}$ の土塊が崩れ落ち, 新たに大きな谷が形成されました。この地震地すべりは, 地質時代の古い埋没谷を埋めるように堆積していた軽石 を多く含むテフラをすべり面として，それを覆う地層が 崩れたと考えられています (田中, 1985) ${ }^{5}$ 。ここの地震地 すべりは, 4 日前に日雨量 $119 \mathrm{~mm}$ という雨が降ったこと もあり，時速70〜 $100 \mathrm{~km}$ という高速で，巨大な岩塊を含 んだ土石流となって流下したと考えられています（中村 ほか編, 2000) ${ }^{6)}$ 。

\subsection{3年台風26号による伊豆大島土砂災害}

2013年の台風26号は伊豆大島に24時間雨量 $800 \mathrm{~mm}$ 超える豪雨をもたらしました。この記録的豪雨を誘因と して，伊豆大島北西部斜面の広い範囲で表層崩壊が発生 しました（図一 4)。

この表層崩壊は14世紀に噴出した溶岩（元町溶岩流） を覆って，斜面と平行に緩く傾いた状態で堆積したレス （風で運ばれて堆積した粘土質の地層）とテフラの互層 のうち，締まりがなく透水性の良い細粒砂質の火山灰層 の底面がすべり面となって，厚さ $50 \mathrm{~cm} 〜 1 \mathrm{~m}$ の表土と その中に入り込んだ植物の根が一体となって滑り落ちた と考えられています (稲垣, 2014) $)^{7)}$ 。溶岩は一般に多孔 質で透水性が高いと考えられますが，実際の火山周辺で は薄い難透水性のレスが溶岩の上を覆っていることがよ くあります。このため，伊豆大島に限らず，難透水性の レスの上に堆積したゆるい砂質のテフラが多量の降雨に より水を含んで浮力をもち，緩勾配の斜面を急速に滑り 落ちる土砂移動様式は少なくありません（たとえば2012 年九州北部豪雨による阿蘇山周辺の表層崩壊)。これも 火山特有の土砂移動現象と捉えてょいでしょう。

\section{5 テフラの 2 次移動}

活火山では，火山活動に伴って大量のテフラが放出さ 


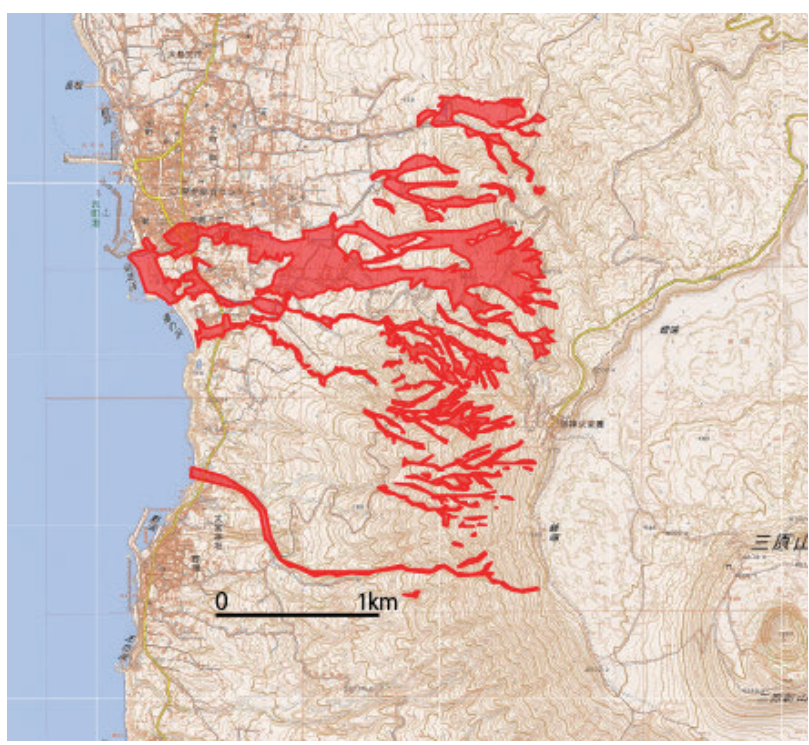

図ー4 2013年の渡島土砂災害時の表層崩壊発生場 (地理院地図に加筆)

れます。テフラの中でも特に軽石は密度が小さく，不安 定な場所にも堆積するため，降雨を受けると崩れ，水と ともに一挙に流出する特性があります。これは，火山噴 火による 2 次災害をもたらす危険があり，警戒を要する 現象と言えましょう。最近でも霧島連峰新燃岳の噴火や 鹿児島県桜島の噴火に際して, 山麓に注意が呼びかけら れています。

\section{引用文献}

1 ）小出博（1955）: 日本の地すべり, 東洋経済新聞社, $257 \mathrm{p}$

2 ）野崎保・菊川茂（2012）：䲸泥と国見泥，立山砂防カルデラ博 物館研究紀要, No. 11,pp. 1-16.

3 ) 藤井昭二 - 中村俊夫 - 酒谷幸彦 - 高橋裕史 - 工藤裕之 $\cdot$ 山野 秀一 (2011)：常願寺川扇状地の形成と災害についての2,3の 知見, 立山砂防カルデラ博物館研究紀要, No. 12, pp.1-10.

4 ）井口隆（1988）：日本における火山帯の山体崩壊の岩首流一磐 梯山，鳥海山，岩手山一，国立防災科学技術センター研究報 告, No. 43, pp. $169-221$.

5 ）田中耕平（1985）：長野県西部地震における斜面崩壊の特徵, 土と基礎，Vol. 33, No.11, pp. 5-11.

6 ）中村浩之 -土屋智 - 井上公夫 - 石川芳治編（2000）：地震砂防, 古今書院, 190p.

7 ) 稲垣秀輝 (2014)：土砂災害の軽減に向けて - 斜面崩壊一, 土 木学会・地盤工学会・日本応用地質学会・日本地すべり学会 平成25年10月台風26号による伊豆大島豪雨災害緊急調査団報 告会 (当日の資料掲載), 報告書掲載, http ://committees.jsce. or.jp/report/system/files/15.pdf（2018年 4 月17日閲覧） 